\title{
Partitioning of nutrient net fluxes across the portal-drained viscera in sheep fed twice daily: effect of dietary protein degradability
}

\author{
Didier Rémond $^{1 *}$, Laurence Bernard ${ }^{2}$, Isabelle Savary-Auzeloux ${ }^{1}$ and Pierre Nozière ${ }^{2}$ \\ ${ }^{1}$ INRA, UMR1019 Unité de Nutrition Humaine, F-63122 St Genès Champanelle, France \\ ${ }^{2}$ INRA, UR1213 Unité de Recherches sur les Herbivores, F-63122 St Genès Champanelle, France
}

(Received 11 July 2008 - Revised 21 November 2008 - Accepted 1 December 2008 - First published online 28 January 2009)

Extrusion is used to decrease leguminous seed protein degradability in the rumen in order to shift part of the dietary protein digestion towards the small intestine. The effect of such displacement of digestion site on the partitioning of nutrient net fluxes across the gastrointestinal tract was studied using four sheep fitted with catheters and blood-flow probes, allowing measurements across the rumen, the mesenteric-drained viscera (MDV) and the portal-drained viscera (PDV). Two diets containing $34 \%$ of pea seeds were tested in a crossover design. They differed only according to pea treatment: raw pea (RP) or extruded pea (EP) diet. Rumen undegradable protein (RUP) accounted for 23 and $40 \%$ of dietary crude protein for RP and EP diets, respectively. Across the rumen wall, ammonia net flux was lower with EP diet, whereas urea net flux was not different. Across the MDV, free amino acid (FAA) net flux was greater with EP diet, whereas peptide amino acid net flux was not different, accounting for $7 \%$ of the non-protein amino acid net release. From RP to EP diet, PDV net flux of ammonia decreased by $23 \%$, whereas FAA net release increased by $21 \%$. The difference in dietary RUP did not affect the PDV net flux of SCFA, 3-hydroxybutyrate, lactate and glucose. In conclusion, the partial shift in pea protein digestion from the rumen to the small intestine did not affect the portal net balance of $\mathrm{N}$, but decreased $\mathrm{N}$ loss from the rumen, and increased amino acid intestinal absorption and portal delivery.

Amino acids: Peptides: Short-chain fatty acids: Portal-drained viscera

Proteins consumed by ruminants are largely degraded in the rumen, up to ammonia production, in order to provide $\mathrm{N}$ required for microbial growth. Consequently, the outflow from the rumen of synthesized microbial protein ensures the largest contribution to amino acids (AA) entering the small intestine. Nevertheless some dietary proteins, more resistant, can escape ruminal degradation and complement the microbial AA source quantitatively and qualitatively to meet maintenance and production needs ${ }^{(1)}$. Conversely, dietary protein readily degraded in the rumen often leads to $\mathrm{N}$ wastage through excessive ammonia absorption from the rumen. Processing has thus been developed in order to decrease rumen degradability of feedstuff, and increase the AA delivery to the intestine. However, an increased flow of protein-N to the duodenum does not necessarily imply an increased availability of AA for anabolic purposes due to the intense metabolic activity of the splanchnic bed. More specifically, the digestive tract is one of the most important AA consumers within the body and participates to about $30 \%$ of the whole-body protein synthesis $^{(2)}$. This metabolism greatly impacts on the quantitative and qualitative net release of AA in the portal vein ${ }^{(3)}$.

Yet, even if the digestive tract is metabolically very active and is withdrawing important quantities of AA, increasing dietary protein supply usually results in a greater portal absorption of AA, as far as the energy supply is adequate to support rumen microbial protein synthesis ${ }^{(4)}$. The specific effect of dietary protein rumen degradability on AA portal delivery is uncertain. Studies often failed to show a clear effect of an increase in rumen undegradable protein (RUP) content of the diet on $\alpha$-amino $\mathrm{N}^{(5-7)}$ portal net release. Other studies led to conflicting observations: an increase in RUP content of the diet increased the portal absorption of free amino acids (FAA) in lactating cows ${ }^{(8)}$, but decreased it in steers ${ }^{(9)}$. Unfortunately in these studies the duodenal flow of AA was not recorded, but several reasons could explain the discrepancies between these studies. First of all, the duodenal flow of AA can be differently affected by increased RUP content of the diet, depending on its impact on microbial protein synthesis ${ }^{(10,11)}$. Second, the level (and nature) of energy supplied in the diet may interfere with the digestive processes (activity of the rumen bacteria, urea recycling) but also with the digestive tract metabolism, which may impact on AA release in the portal vein ${ }^{(12)}$. Finally, low-molecularweight peptides that are generally not taken into account in the determination of AA balances could significantly contribute to AA net release into the portal vein and this contribution could be affected by diet composition ${ }^{(13)}$. Absorption of dietary peptides is still controversial, yet it is noteworthy

Abbreviations: AA, amino acid; EP, extruded pea; FAA, free amino acid; MDV, mesenteric-drained viscera; PAA, peptide amino acid; PDV, portal-drained viscera;

RP, raw pea; RUP, rumen undegradable protein.

* Corresponding author: Dr Didier Rémond, fax +334736247 55, email dremond@clermont.inra.fr 
that significant amounts of low-molecular-weight peptides flow out of the rumen ${ }^{(14)}$ and are available for absorption in the proximal part of the intestine.

In this context, the present study aimed to determine the effect, at similar $\mathrm{N}$ and energy intake, of a shift in dietary protein digestion from the rumen to the small intestine on $\mathrm{N}$ transactions across the different segments of the gut. To reach this goal we used two diets containing raw pea (RP) or extruded pea (EP) seeds, for which in vivo rumen digestion and intestinal nutrient flows were previously reported ${ }^{(10)}$. We particularly emphasized the impact of the rumen protein digestibility on the various fractions of $\mathrm{N}$ appearing in the portal vein (ammonia, FAA and peptides) and the urea recycling, as well as on the consequences on the energetic nutrients profile absorbed in the portal vein.

\section{Materials and methods}

Animals, housing and diets

Four mature Texel wethers (mean live weight 58 (SD 3) $\mathrm{kg}$ ) were surgically fitted with a rumen cannula $(35 \mathrm{~mm}$ internal diameter) and catheters in the right ruminal vein, the cranial mesenteric vein $(2-4 \mathrm{~cm}$ upstream of the ileocaecocolic vein junction), the portal vein and a mesenteric artery. Transittime ultrasonic blood flow probes (Transonic Systems Inc., Ithaca, NY, USA) were implanted around the portal vein, the mesenteric vein and the right ruminal artery ${ }^{(15)}$. Correct positioning of the probes and catheters was confirmed by necropsy at the end of the trial. All procedures were in accordance with the guidelines formulated by the European Community for the use of experimental animals (L358-86/609/EEC). Animals were allowed a 3-week recovery from surgery before allocation to the trial.

Sheep were housed in individual pens, in rooms under continuous lighting with controlled temperature $\left(19-23^{\circ} \mathrm{C}\right)$. They were fed $1160 \mathrm{~g} \mathrm{DM} / \mathrm{d}$ in two equal meals at $12 \mathrm{~h}$ intervals (07.30 hours, 19.30 hours), providing $31.6 \mathrm{~g} \mathrm{~N} / \mathrm{d}$ and $12 \mathrm{MJ}$ metabolizable energy/d. The sheep had free access to water and salt blocks.

Two diets were tested in a cross-over design experiment. They contained (\% of DM) $66 \%$ chopped cocksfoot hay and $34 \%$ concentrate based on pea seeds (Pisum sativum cultivar Solara), and differed according to the treatment applied to the pea seeds: RP diet and EP diet. Pea extrusion was performed on a single-screw extruder $\left(18 \% \mathrm{H}_{2} \mathrm{O}\right.$ at $185^{\circ} \mathrm{C}$, specific mechanical energy delivery $102 \mathrm{Wh} / \mathrm{kg}$ ) after conditioning for $10 \mathrm{~min}$ at $130^{\circ} \mathrm{C}$. This treatment decreased in vivo rumen degradability of pea protein from 80 to $47 \%(10)$. The diets were formulated with pea seeds accounting for approximately $50 \%$ of the crude protein in each diet. Chemical composition of the diets is given in Table 1. RUP accounted for 23 and $40 \%$ of dietary crude protein for RP and EP diets, respectively. Animals were allowed to adjust to the diet for at least 2 weeks before sampling.

\section{Experimental procedures}

Blood flow was measured continuously (from 05.30 to 17.30 hours) with an transit-time ultrasonic flowmeter interfaced with a computer for data acquisition. Blood samples $(10 \mathrm{ml})$
Table 1. Ingredients and chemical analysis of raw pea (RP) and extruded pea (EP) diets

\begin{tabular}{lcc}
\hline Item & RP diet & EP diet \\
\hline Ingredients (g/kg DM) & & \\
Cocksfoot hay & 660 & 660 \\
RP seeds & 338 & - \\
EP seeds & - & 338 \\
Mineral and vitamin mix & 2 & 2 \\
Chemical analysis (g/kg DM) & & \\
Organic matter & 929 & 929 \\
Crude protein* & 172 & 172 \\
Starch & 151 & 150 \\
Neutral-detergent fibre & 449 & 451 \\
Acid-detergent fibre & 244 & 240 \\
\hline * Dietary N $\times 6.25$. & &
\end{tabular}

were simultaneously withdrawn through the four catheters at $06.00,08.00,09.00,10.00,12.00,14.00$ and 16.00 hours. They were collected into cold syringes containing anticoagulant (Monovett, Starstedt, Mosheim, France). Samples were rapidly placed on ice. Packed cell volume was determined, and blood was subsampled. A whole-blood sample $(1.5 \mathrm{ml})$ was frozen in liquid $\mathrm{N}_{2}$ and stored at $-80^{\circ} \mathrm{C}$ for SCFA analysis, while another subset sample $(2 \mathrm{ml})$ was used for immediate analyses of $\mathrm{Hb}$, urea and ammonia. A $2 \mathrm{ml}$ fraction of blood was deproteinized by adding $0.2 \mathrm{ml} 6 \mathrm{M}-\mathrm{HClO}_{4}$, mixing and centrifuging $\left(10000 \mathrm{~g}\right.$ for $15 \mathrm{~min}$ at $\left.4^{\circ} \mathrm{C}\right)$. Supernatant $(1.2 \mathrm{ml})$ was neutralized by addition of $0.115 \mathrm{ml} 6 \mathrm{M}$ $\mathrm{KOH}$; the mixture was stored at $4^{\circ} \mathrm{C}$ for $30 \mathrm{~min}$, centrifuged $\left(10000 \mathrm{~g}\right.$ for $15 \mathrm{~min}$ at $\left.4^{\circ} \mathrm{C}\right)$, and the supernantant was stored at $-80^{\circ} \mathrm{C}$ for glucose, lactate and 3-hydroxybutyrate analyses. D-Glucosaminic acid $(1 \mathrm{ml}, 0.125 \mathrm{~mm})$ was added to a $1 \mathrm{ml}$ blood fraction which was then deproteinized by addition of $0.1 \mathrm{ml}$ sulphosalicylic acid (40\%, w/v). Samples were mixed, allowed to stand for $15 \mathrm{~min}$ at room temperature, and precipitated proteins were removed by two successive centrifugations at $10000 \mathrm{~g}$ for $15 \mathrm{~min}$ at $4^{\circ} \mathrm{C}$. Supernatant was frozen $\left(-80^{\circ} \mathrm{C}\right)$ for later FAA analysis. Finally, the remaining blood fraction $(3.5 \mathrm{ml})$ was centrifuged $(1500 \mathrm{~g}$ for $10 \mathrm{~min}$ at $4^{\circ} \mathrm{C}$ ), and plasma was recovered. The plasma $(2 \mathrm{ml})$ was then deproteinized with $0.2 \mathrm{ml}$ sulphosalicylic acid $(40 \%, \mathrm{w} / \mathrm{v})$ following addition of norleucine $(0.2 \mathrm{ml}$, $1.25 \mathrm{~mm})$. Deproteinized plasma was frozen $\left(-80^{\circ} \mathrm{C}\right)$ for later low-molecular-weight $(<3 \mathrm{kDa})$ peptide amino acid (PAA) analysis. The determination of urea, ammonia, Hb, glucose, lactate, 3-hydroxybutyrate, SCFA, FAA and PAA concentrations was carried out as previously described ${ }^{(13)}$.

Rumen liquor was collected immediately after each blood sampling. Samples were filtered through nylon gauze. After $\mathrm{pH}$ measurement, rumen fluid was centrifuged $(800 \mathrm{~g}$ for $10 \mathrm{~min}$ at $4^{\circ} \mathrm{C}$ ), and the supernatant was then centrifuged at $27000 \mathrm{~g}$ for $20 \mathrm{~min}$ at $4^{\circ} \mathrm{C}$. The supernatant was subsampled for analyses of SCFA, ammonia-N, FAA and PAA $(<10 \mathrm{kDa})^{(13)}$.

\section{Calculations and statistics}

PAA concentration was calculated as the difference in AA concentration between samples taken before and after acid hydrolysis. Peptide-bound glutamate and aspartate were corrected for glutamate and aspartate released from glutamine and asparagine during hydrolysis. The mean blood flow to 
the rumen for each sampling time $t$ was generated by integrating instantaneous flow over a period ranging from $t-[(t-$ $\left.\left.t_{-1}\right) / 2\right]$ to $t+\left[\left(t-t_{-1}\right) / 2\right]$. Plasma flow (PF) was calculated using the following equation: $\mathrm{PF}=\mathrm{BF} \times(1-\mathrm{PCV})$, where $\mathrm{BF}$ represents blood flow, and PCV (packed cell volume) is blood flowing within the probe. Ammonia, urea, FAA, SCFA, glucose, lactate and hydroxybutyrate net fluxes were calculated for whole blood whereas PAA net fluxes were calculated for plasma. Net fluxes of metabolite (M) were calculated with the following equation: M net flux $=\left(\left([\mathrm{M}]_{\mathrm{v}} \times[\mathrm{Hb}]_{\mathrm{a}} /[\mathrm{Hb}]_{\mathrm{v}}\right)-[\mathrm{M}]_{\mathrm{a}}\right) \times \mathrm{F}$, where $[\mathrm{M}]_{\mathrm{v}}$ and $[\mathrm{M}]_{\mathrm{a}}$ represent the venous and the arterial concentrations of the metabolite $\mathrm{M}$ in blood or plasma, $[\mathrm{Hb}]_{\mathrm{a}} /[\mathrm{Hb}]_{\mathrm{v}}$ represents the ratio between the arterial and the venous blood concentrations of $\mathrm{Hb}$, and $\mathrm{F}$ represents blood or plasma flow. Hb concentration ratio was used to correct fluxes for water movement across vessels. A positive net flux indicates release of a nutrient, whereas a negative net flux implies uptake. Net metabolite fluxes across the rumen wall were estimated to be twice that in the right ruminal vein. With the preparation used in this experiment (mesenteric catheter just upstream of the ileocaecocolic vein junction), the cranial mesenteric vein drained about $84 \%$ of the whole small intestine, and that about $10 \%$ of the cranial mesenteric vein drainage originated from the colon (accounting for $20 \%$ of colon drainage $)^{(16)}$. With such a preparation, mesenteric-drained viscera (MDV) flux did not take into account the proximal duodenum and the distal ileum. NonMDV fluxes were calculated as the difference between portal-drained viscera (PDV) and MDV fluxes. The quantity of metabolite transferred across the PDV tissues within the $12 \mathrm{~h}$ period was estimated from the area under the curve (calculated by integrating time-variations in net fluxes, trapezoidal method). Daily average of metabolite net flux was estimated on the assumption that all $12 \mathrm{~h}$ periods were equivalent. Summations of net portal energy fluxes were based on heats of combustion of 876 (acetate), 1528 (propionate), 2310 (fourcarbon SCFA and $\beta$-hydroxybutyrate), 2838 (five-carbon SCFA), 1368 (lactate), 2813 (glucose) and 2001 (AA) kJ metabolizable energy/mol.

Daily averages of studied traits were analysed by ANOVA using the general linear model procedure of SAS (release 8.1; SAS Institute Inc., Cary, NC, USA), with animal and diet as factors. Time and time $\times$ diet effects on studied traits were tested using the repeated option of the PROC MIXED procedure of SAS, with animal as random effect and with time, diet, and time $\times$ diet as factors. When significant time $\times$ diet interaction was found, the LS-MEANS procedure was used to test differences at specific times, among diets, and within diet compared with pre-meal values.

\section{Results}

All catheters and blood flow probes remained patent throughout the experiment. The sheep consumed all their meal in less than $45 \mathrm{~min}$.

The patterns of intraruminal traits ( $\mathrm{pH}, \mathrm{SCFA}$, ammonia, PAA) throughout a feeding cycle are presented in Fig. 1. All traits showed significant variations with time $(P<0.001)$. The time-variations in rumen $\mathrm{pH}$ and SCFA were not significantly affected by the diet. Conversely, with EP diet postprandial increase in ammonia was lessened compared to RP diet.
FAA in rumen content were detected only during the first $2 \mathrm{~h}$ following the meal; $1 \mathrm{~h}$ after the meal, their concentration was greater $(P<0.05)$ with RP than with EP diet. With both diets, PAA concentrations in the rumen significantly increased after the meal. Throughout the sampling period PAA concentration was greater with EP than with RP diet. The daily averages of ruminal traits are presented in Table 2. The main differences between the two diets were a concomitant decrease in ammonia concentration $(P<0.05)$ and increase in PAA concentration with EP diet $(P<0 \cdot 01)$.

MDV blood flow did not significantly vary throughout the $12 \mathrm{~h}$ feeding cycle, whereas portal and ruminal blood flow increased during the $90 \mathrm{~min}$ following food delivery, and thereafter decreased gradually, returning to prefeeding levels. There was no significant interaction between time and diet $(P>0 \cdot 10)$, and throughout the $12 \mathrm{~h}$ feeding cycle blood flow averaged 3018 (SD 123), 693 (SD 58), 566 (SD 62) $\mathrm{ml} / \mathrm{min}$ for PDV, MDV and rumen, respectively. Values for $[\mathrm{Hb}]_{\mathrm{a}} /[\mathrm{Hb}]_{\mathrm{v}}$ were not affected by the diet, giving average results of 1.011 (SD 0.003), 1.012 (SD 0.03) and 1.008 (SD 0.03 ) for PDV, MDV and rumen, respectively.

Arterial blood ammonia concentration was not affected by the time of day and the diet and averaged 1.37 (SD 0.31) mg $\mathrm{N} / 1$. Throughout the $12 \mathrm{~h}$ feeding cycle blood urea concentration was greater $(P<0.001)$ with RP than with EP diet; daily means were 188 (SD 21) and 137 (SD 20) mg N/l for $\mathrm{RP}$ and EP, respectively. Total FAA concentration in arterial blood and total PAA concentration in arterial plasma were not affected by the time of day. Daily averages of individual FAA and PAA are presented in Table 3. Neither FAA nor PAA arterial concentration was significantly affected by the diet. Arterial glucose and lactate concentrations were both affected by the time of day. For both diets, arterial glucose was acutely decreased during the first hour following the meal $(P<0.01)$, while arterial lactate was greater $(P<0.05)$ than the pre-feeding value during the $4 \mathrm{~h}$ following the meal. Daily averages of arterial glucose and lactate were 2.94 (SD $0 \cdot 13$ ) and $0.62(\mathrm{SD} 0 \cdot 07) \mathrm{mm}$, respectively. Daily averages of arterial concentrations of acetate, propionate, butyrate, isobutyrate, valerate, isovalerate and 3-hydroxybutyrate were not affected by the diet and were 1218 (SD 74), 27.6 (SD 4.5), 12.2 (SD 4.1), 2.9 (SD 0.7), 1.1 (SD 0.3), 2.5 (SD 0.7) and 600 (SD 100) $\mu \mathrm{M}$, respectively. For each of these metabolites, arterial concentration varied throughout the feeding cycle $(P<0.05)$, with their values being greater postprandially than before meal distribution; the interaction between time and diet was never significant.

Total and individual FAA net fluxes across the rumen, MDV and PDV did not show significant variations within the feeding cycle. Daily averages of these fluxes across the MDV and PDV are presented in Table 4. Daily average of FAA net flux across the rumen was not affected by the diet and was 53 (SD 27) and 21 (SD 10) mmol/d for total and essential FAA, respectively. Total and individual PAA net fluxes across the MDV and PDV did not significantly vary within the feeding cycle. Daily averages of these fluxes are presented in Table 5. Net fluxes of PAA across the rumen were not recorded. Urea and ammonia net fluxes across the MDV were not affected by the time of day $(P>0 \cdot 10)$ and there was no interaction between time and diet. Urea and ammonia net fluxes across the rumen and PDV showed significant 
(a)

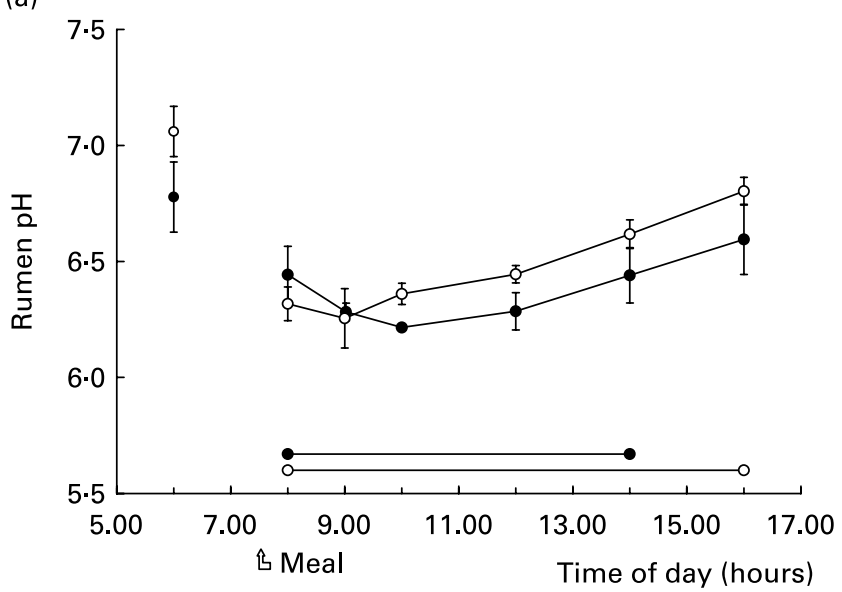

(b)

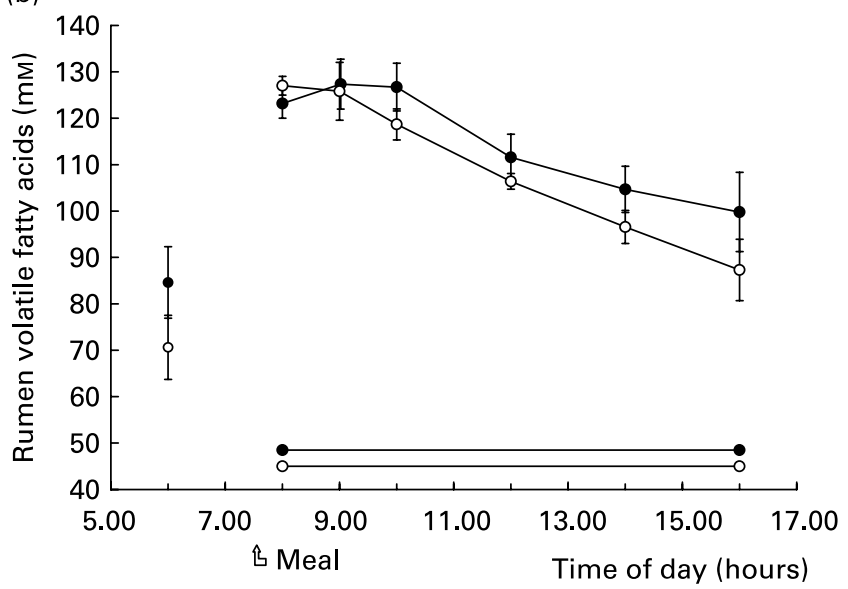

(d)

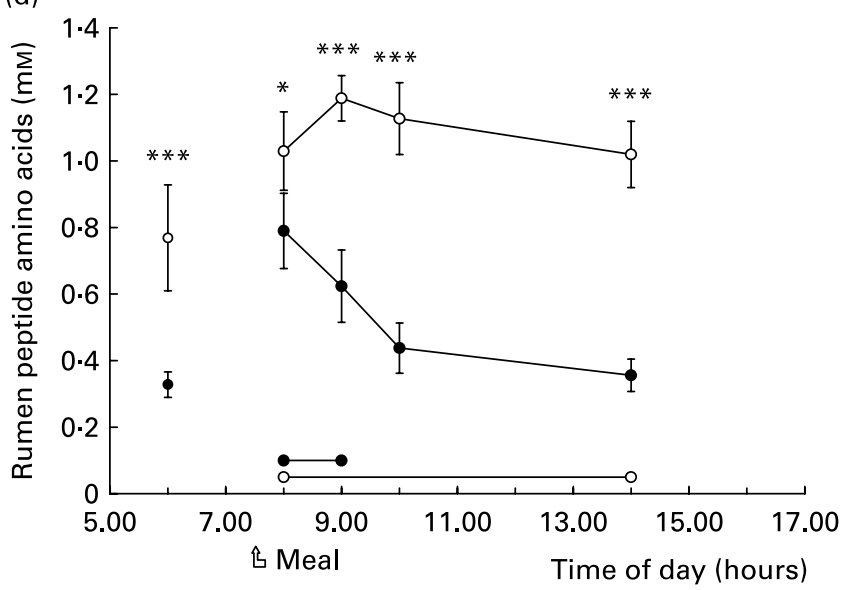

(c)

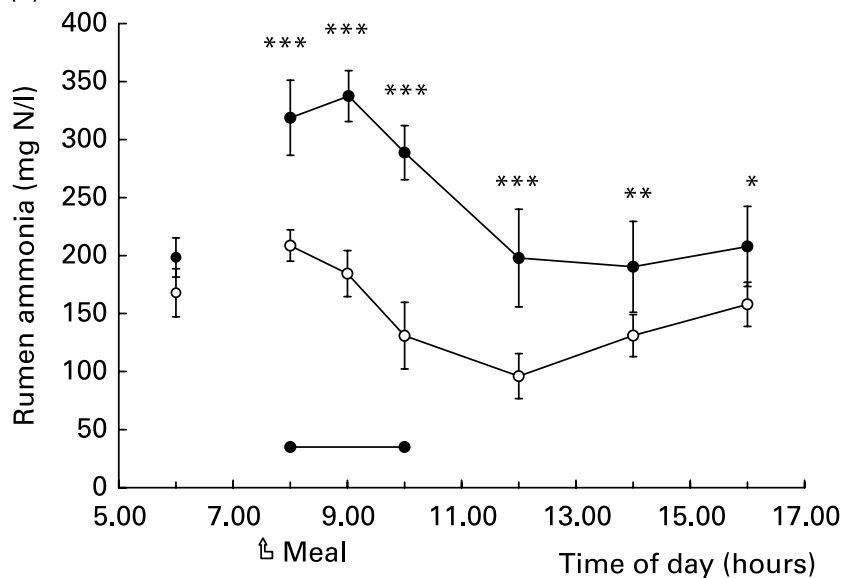

Fig. 1. Patterns of $\mathrm{pH}(\mathrm{a})$, total volatile fatty acid (b), ammonia (c) and peptide $(<10 \mathrm{kDa})$ amino acid (d) concentrations in the rumen of sheep fed twice daily with cocksfoot hay supplemented with raw $(\bullet)$ or extruded $(O)$ pea seeds. Values are means with their standard errors depicted by vertical bars $(n 4)$. Data were analysed by a mixed-model ANOVA, and time $\times$ diet interaction was significant for ammonia concentration $(P<0.001)$, and peptide amino acid concentration $(P<0.05)$, but not for $\mathrm{pH}(P=0.11)$ and total volatile fatty acid concentration $(P=0.53)$. Mean values for the two diets were significantly different: ${ }^{*} P<0.05$, ${ }^{* \star} P<0.01,{ }^{* * *} P<0.001$. Time effect was significant for the four measures $(P<0.001)$, and horizontal lines at the bottom of the graph indicate a significant difference $(P<0.05)$ from pre-meal value for each curve.

variations $(P<0 \cdot 001)$ within the feeding cycle (Fig. 2). Daily averages of urea and ammonia net fluxes across the rumen, MDV and PDV are presented in Table 6. Net fluxes of acetate, propionate, isobutyrate, valerate, isovalerate, 3-hydroxybutyrate and lactate across the MDV were not affected by the time of day $(P>0 \cdot 10)$. Butyrate net uptake and glucose net release by the MDV was greater postprandially than before feed distribution $(P<0 \cdot 01)$. Whatever the diet, acetate, propionate, butyrate, isobutyrate, valerate, isovalerate, 3-hydroxybutyrate and lactate net fluxes across the rumen and PDV significantly increased after the meal $(P<0.01$; data not shown). For all these traits, the interaction time $\times$ diet was not significant $(P>0 \cdot 10)$. Relationships between instantaneous net fluxes of SCFA across the rumen wall and SCFA concentration in the rumen are presented in Fig. 3. Glucose net flux across the gastrointestinal tract was not affected by the diet. The dynamics of glucose net flux across the MDV and PDV are presented in Fig. 4. Postprandial area under the curve (calculated by integrating the difference between pre-feeding flux and observed flux, trapezoidal method) suggested a release of dietary glucose of $16 \cdot 2$ (SD 1.5) and 18.4 (SD 2.4)
Table 2. Daily values of $\mathrm{pH}$, ammonia $\left(\mathrm{NH}_{3}\right)$, free amino acids (FAA), low-molecular-weight peptide amino acids (PAA) and total volatile fatty acids (VFA) concentrations, and molar proportions of individual VFA, in rumen fluid of sheep fed cocksfoot hay supplemented with raw pea (RP) or extruded pea (EP) seeds*

(Mean values with their standard errors for four sheep)

\begin{tabular}{|c|c|c|c|c|c|}
\hline \multirow[b]{2}{*}{ Item } & \multicolumn{2}{|c|}{$\mathrm{RP}$} & \multicolumn{2}{|c|}{ EP } & \multirow[b]{2}{*}{$P$} \\
\hline & Mean & SE & Mean & SE & \\
\hline $\mathrm{pH}$ & 6.46 & 0.09 & $6 \cdot 61$ & 0.05 & 0.075 \\
\hline $\mathrm{NH}_{3}(\mathrm{mg} \mathrm{N} / \mathrm{l})$ & 233 & 29 & 147 & 19 & 0.019 \\
\hline FAA (mM) & 0.07 & 0.02 & 0.01 & 0.00 & 0.076 \\
\hline PAA (mм) & 0.44 & 0.05 & 1.04 & $0 \cdot 10$ & 0.002 \\
\hline Total VFA (mM) & 108 & 4 & 100 & 3 & 0.079 \\
\hline \multicolumn{6}{|c|}{ Molar proportions of VFA (\%) } \\
\hline Acetate & $66 \cdot 2$ & 0.3 & 64.9 & $1 \cdot 2$ & 0.397 \\
\hline Propionate & 18.5 & 0.5 & $20 \cdot 7$ & 1.6 & 0.302 \\
\hline Butyrate & $12 \cdot 0$ & 0.3 & $11 \cdot 3$ & 0.4 & 0.099 \\
\hline Isobutyrate & $1 \cdot 1$ & $0 \cdot 1$ & $1 \cdot 1$ & $0 \cdot 1$ & 0.858 \\
\hline Valerate & 0.9 & $0 \cdot 1$ & 0.9 & $0 \cdot 1$ & 0.572 \\
\hline Isovalerate & $1 \cdot 2$ & 0.2 & $1 \cdot 1$ & 0.2 & 0.764 \\
\hline
\end{tabular}

${ }^{\star}$ For details of procedures and diets, see the Materials and methods section and Table 1. 
Table 3. Daily values of blood arterial concentration $(\mu \mathrm{M})$ of free amino acids (FAA), and plasma arterial concentration $(\mu \mathrm{M})$ of peptide amino acids (PAA) in sheep fed cocksfoot hay supplemented with raw pea (RP) or extruded pea (EP) seeds ${ }^{*}$

(Mean values with their standard errors for four sheep)

\begin{tabular}{|c|c|c|c|c|c|c|c|c|c|c|}
\hline \multirow[b]{3}{*}{ Item } & \multicolumn{5}{|c|}{ FAA } & \multicolumn{5}{|c|}{ PAA } \\
\hline & \multicolumn{2}{|c|}{$\mathrm{RP}$} & \multicolumn{2}{|c|}{ EP } & \multirow[b]{2}{*}{$P$} & \multicolumn{2}{|c|}{$\mathrm{RP}$} & \multicolumn{2}{|c|}{ EP } & \multirow[b]{2}{*}{$P$} \\
\hline & Mean & SE & Mean & $\mathrm{SE}$ & & Mean & SE & Mean & SE & \\
\hline Aspartic acid & 22 & 3 & 23 & 4 & 0.81 & 3 & 1 & 4 & 1 & 0.63 \\
\hline Threonine & 115 & 18 & 138 & 26 & 0.60 & 15 & $6 \cdot 2$ & 10 & 7 & 0.33 \\
\hline Serine & 98 & 10 & 97 & 10 & 0.88 & 1 & 2 & 0 & 1 & 0.61 \\
\hline Asparagine & 51 & 2 & 54 & 6 & 0.67 & - & & - & & \\
\hline Glutamic acid & 90 & 13 & 80 & 2 & 0.54 & 19 & 7 & 20 & 8 & 0.97 \\
\hline Glutamine & 269 & 23 & 271 & 28 & 0.96 & - & & - & & \\
\hline Proline & 64 & 4 & 75 & 5 & 0.11 & 7 & 2 & 2 & 3 & 0.09 \\
\hline Glycine & 538 & 20 & 576 & 17 & 0.20 & 149 & 6 & 124 & 13 & $0 \cdot 10$ \\
\hline Alanine & 144 & 9 & 155 & 10 & 0.57 & 24 & 2 & 19 & 3 & 0.22 \\
\hline Citrulline & 167 & 12 & 153 & 9 & 0.30 & - & & - & & \\
\hline Valine & 164 & 11 & 199 & 4 & 0.10 & 19 & 4 & 10 & 3 & 0.20 \\
\hline Cysteine & 8 & 2 & 9 & 2 & 0.89 & - & & - & & \\
\hline Methionine & 14 & 2 & 15 & 1 & 0.90 & - & & _- & & \\
\hline Isoleucine & 75 & 2 & 86 & 4 & 0.11 & 5 & 1 & 4 & 1 & 0.80 \\
\hline Leucine & 90 & 8 & 109 & 6 & 0.18 & 12 & 4 & 12 & 4 & 0.99 \\
\hline Tyrosine & 49 & 8 & 59 & 5 & 0.48 & - & & - & & \\
\hline Phenylalanine & 30 & 6 & 35 & 3 & 0.60 & 6 & 1 & 4 & 1 & 0.61 \\
\hline Ornithine & 147 & 28 & 151 & 21 & 0.93 & - & & - & & \\
\hline Lysine & 153 & 15 & 173 & 9 & 0.36 & 13 & 1 & 12 & 4 & 0.92 \\
\hline Histidine & 87 & 9 & 94 & 7 & 0.71 & 13 & 2 & 13 & 3 & 0.96 \\
\hline Arginine & 113 & 27 & 132 & 15 & 0.66 & 6 & 2 & 3 & 2 & 0.83 \\
\hline Total AA & 2487 & 94 & 2683 & 86 & 0.30 & 292 & 16 & 252 & 33 & 0.25 \\
\hline Essential AA & 729 & 55 & 848 & 44 & 0.31 & 81 & 10 & 69 & 16 & 0.66 \\
\hline
\end{tabular}

AA, amino acid.

${ }^{*}$ For details of procedures and diets, see the Materials and methods section and Table 1.

Table 4. Mesenteric-drained viscera (MDV) and portal-drained viscera (PDV) net flux of blood free amino acids in sheep fed cocksfoot hay supplemented with raw pea (RP) or extruded pea (EP) seeds*

(Mean values with their standard errors for four sheep)

\begin{tabular}{|c|c|c|c|c|c|c|c|c|c|c|}
\hline \multirow[b]{3}{*}{ Item } & \multicolumn{5}{|c|}{ MDV net flux (mmol/d) } & \multicolumn{5}{|c|}{ PDV net flux (mmol/d) } \\
\hline & \multicolumn{2}{|c|}{$\mathrm{RP}$} & \multicolumn{2}{|c|}{ EP } & \multirow[b]{2}{*}{$P$} & \multicolumn{2}{|c|}{$\mathrm{RP}$} & \multicolumn{2}{|c|}{ EP } & \multirow[b]{2}{*}{$P$} \\
\hline & Mean & SE & Mean & SE & & Mean & SE & Mean & SE & \\
\hline Aspartic acid & 7 & 1 & 7 & 1 & 0.96 & 4 & 1 & 6 & 2 & 0.34 \\
\hline Threonine & 65 & 7 & 76 & 5 & 0.00 & 33 & 2 & 48 & 6 & 0.03 \\
\hline Serine & 79 & 6 & 77 & 2 & 0.67 & 47 & 3 & 57 & 2 & 0.06 \\
\hline Asparagine & 62 & 6 & 58 & 2 & 0.59 & 30 & 5 & 36 & 2 & 0.34 \\
\hline Glutamic acid & 18 & 4 & 21 & 2 & 0.49 & -1 & 2 & 5 & 3 & 0.17 \\
\hline Glutamine & -5 & 6 & 6 & 2 & 0.15 & -59 & 5 & -60 & 12 & 0.90 \\
\hline Proline & 34 & 3 & 36 & 4 & 0.60 & 24 & 3 & 26 & 14 & 0.82 \\
\hline Glycine & 103 & 13 & 142 & 13 & 0.06 & 77 & 4 & 101 & 5 & 0.15 \\
\hline Alanine & 123 & 8 & 134 & 5 & 0.25 & 98 & 4 & 101 & 3 & 0.32 \\
\hline Citrulline & 25 & 6 & 31 & 9 & 0.19 & 26 & 4 & 32 & 9 & 0.31 \\
\hline Valine & 80 & 7 & 92 & 7 & 0.04 & 47 & 4 & 54 & 10 & 0.38 \\
\hline Cysteine & 3 & 1 & 4 & 1 & $0 \cdot 22$ & -1 & 0 & 0 & 1 & 0.44 \\
\hline Methionine & 17 & 1 & 17 & 1 & 0.95 & 11 & 2 & 11 & 4 & 0.64 \\
\hline Isoleucine & 59 & 4 & 66 & 4 & 0.02 & 33 & 3 & 41 & 2 & 0.01 \\
\hline Leucine & 73 & 6 & 84 & 4 & 0.07 & 43 & 5 & 56 & 1 & 0.04 \\
\hline Tyrosine & 30 & 4 & 34 & 1 & 0.33 & 19 & 4 & 27 & 1 & 0.08 \\
\hline Phenylalanine & 31 & 3 & 36 & 2 & 0.27 & 25 & 3 & 33 & 1 & 0.07 \\
\hline Ornithine & 10 & 4 & 16 & 4 & 0.17 & 16 & 4 & 15 & 3 & 0.82 \\
\hline Lysine & 80 & 6 & 77 & 8 & 0.04 & 57 & 5 & 55 & 3 & 0.29 \\
\hline Histidine & 20 & 1 & 22 & 1 & 0.04 & 14 & 1 & 16 & 1 & $0 \cdot 15$ \\
\hline Arginine & 33 & 2 & 38 & 3 & $0 \cdot 20$ & 17 & 3 & 25 & 4 & 0.27 \\
\hline Total AA & 946 & 72 & 1073 & 60 & 0.03 & 562 & 41 & 683 & 23 & 0.00 \\
\hline Essential AA & 424 & 30 & 470 & 26 & 0.00 & 264 & 20 & 314 & 18 & 0.02 \\
\hline
\end{tabular}

AA, amino acid

${ }^{*}$ For details of procedures and diets, see the Materials and methods section and Table 1. 
Table 5. Mesenteric-drained viscera (MDV) and portal-drained viscera (PDV) net fluxes of plasma peptide amino acids in sheep fed cocksfoot hay supplemented with raw pea (RP) or extruded pea (EP) seeds*

(Mean values with their standard errors for four sheep)

\begin{tabular}{|c|c|c|c|c|c|c|c|c|c|c|}
\hline \multirow[b]{3}{*}{ Item } & \multicolumn{5}{|c|}{ MDV net flux (mmol/d) } & \multicolumn{5}{|c|}{ PDV net flux (mmol/d) } \\
\hline & \multicolumn{2}{|c|}{$\mathrm{RP}$} & \multicolumn{2}{|c|}{ EP } & \multirow[b]{2}{*}{$P$} & \multicolumn{2}{|c|}{$\mathrm{RP}$} & \multicolumn{2}{|c|}{ EP } & \multirow[b]{2}{*}{$P$} \\
\hline & Mean & SE & Mean & SE & & Mean & SE & Mean & SE & \\
\hline Aspartic acid & 1.4 & 1.5 & $-1 \cdot 6$ & 1.4 & $0 \cdot 10$ & 1.6 & 0.3 & 0.0 & 1.6 & 0.33 \\
\hline Threonine & 11.5 & $6 \cdot 1$ & $10 \cdot 4$ & 3.4 & 0.80 & $12 \cdot 2$ & 4.3 & $14 \cdot 8$ & 2.7 & 0.54 \\
\hline Serine & -0.3 & 1.2 & -1.6 & 1.6 & 0.21 & 0.4 & 1.7 & $1 \cdot 1$ & 1.9 & 0.81 \\
\hline Glutamic acid & 4.2 & $5 \cdot 1$ & 4.4 & $3 \cdot 2$ & 0.95 & $22 \cdot 1$ & 8.4 & $20 \cdot 4$ & $5 \cdot 3$ & 0.88 \\
\hline Proline & 3.0 & 0.9 & 3.5 & 1.3 & 0.37 & 4.6 & 3.2 & 4.9 & 3.4 & 0.91 \\
\hline Glycine & $16 \cdot 7$ & 8.5 & $17 \cdot 3$ & 4.4 & 0.95 & $37 \cdot 2$ & $17 \cdot 7$ & 38.5 & $10 \cdot 9$ & 0.89 \\
\hline Alanine & 3.6 & 4.0 & 5.4 & $2 \cdot 4$ & 0.69 & $6 \cdot 0$ & 5.6 & $8 \cdot 0$ & 3.2 & 0.55 \\
\hline Valine & $5 \cdot 4$ & $2 \cdot 3$ & $7 \cdot 6$ & $1 \cdot 1$ & 0.38 & $8 \cdot 7$ & 2.9 & $14 \cdot 1$ & 1.5 & 0.04 \\
\hline Cysteine & - & & - & & - & - & & - & & - \\
\hline Methionine & - & & - & & - & - & & - & & - \\
\hline Isoleucine & 4.2 & $2 \cdot 0$ & 3.6 & 1.0 & 0.67 & $3 \cdot 1$ & 1.7 & 4.3 & $2 \cdot 1$ & 0.15 \\
\hline Leucine & $7 \cdot 1$ & 3.0 & $5 \cdot 4$ & 0.7 & 0.54 & 8.9 & $5 \cdot 2$ & $8 \cdot 3$ & 4.2 & 0.76 \\
\hline Tyrosine & - & & - & & - & - & & - & & - \\
\hline Phenylalanine & 2.5 & 1.5 & $2 \cdot 8$ & 0.5 & 0.79 & 3.0 & 0.9 & 5.9 & 2.9 & 0.26 \\
\hline Lysine & $7 \cdot 0$ & $2 \cdot 3$ & 5.9 & 1.5 & 0.69 & $13 \cdot 2$ & 4.6 & 9.0 & 1.5 & 0.42 \\
\hline Histidine & 1.7 & 1.3 & 0.9 & 0.8 & 0.67 & $6 \cdot 6$ & 1.6 & 3.5 & 1.9 & 0.23 \\
\hline Arginine & 2.5 & 2.5 & 3.2 & 0.9 & 0.80 & 8.0 & 3.7 & 9.2 & 5.0 & 0.78 \\
\hline Total AA & 71 & 35 & 69 & 20 & 0.91 & 136 & 40 & 118 & 22 & 0.56 \\
\hline Essential AA & 39 & 15 & 37 & 7 & 0.83 & 56 & 11 & 60 & 12 & 0.46 \\
\hline
\end{tabular}

AA, amino acid.

${ }^{*}$ For details of procedures and diets, see the Materials and methods section and Table 1.

g/d across the MDV and PDV, respectively. The daily averages of acetate, propionate, butyrate, isobutyrate, valerate, isovalerate, 3-hydroxybutyrate, lactate and glucose net fluxes across the rumen, MDV and PDV are presented in Table 7. Summation of net portal energy fluxes was 9.24 and $9.59 \mathrm{MJ}$ metabolizable energy/d for RP and EP diets, respectively.

\section{Discussion}

Leguminous seeds, such as lupin and pea, suffer from high protein degradability in the rumen which gives them a low nitrogenous value in feeding systems for ruminants. However, this handicap could be overcome using adapted technological processes such as lowered mechanical treatment (cracking $v$. grinding) or heat treatments. Extrusion was shown to efficiently reduce rumen degradability of pea and lupin proteins, leading to a reduced ammonia- $\mathrm{N}$ concentration in the rumen and an increased dietary-N flow to the duodenum ${ }^{(10,11)}$. Microbial-N flow to the duodenum was not affected by pea extrusion, but decreased with lupin extrusion. Interestingly, with EP, not only the average concentration of soluble nonammonia-N in the rumen was greater than with RP, but also less variable throughout the feeding cycle, ensuring a constant availability of non-ammonia-N for microbial synthesis, that could partly explain the increase in the efficiency of bacterial protein synthesis observed with pea extrusion. The composition of soluble non-ammonia-N in the rumen was investigated in the study with lupin ${ }^{(11)}$, and the rumen concentration of low-molecular-weight peptide was greater with EP than with RP seeds. Although the quantitative significance of peptide absorption across the gut wall is still controversial, when high concentrations of peptides are generated in the rumen, PAA could significantly contribute to AA flux across the portal vein viscera ${ }^{(15)}$. In this general context, the present experiment was conducted to evaluate how the decrease in pea protein rumen degradability due to the extrusion process ${ }^{(10)}$ impacts ammonia absorption, urea recycling, FAA and PAA absorption and overall nutrient net fluxes across the PDV.

\section{Nitrogen balance in the total digestive tract}

From previous data obtained with sheep of the same breed and similar diets ${ }^{(10)}$, apparent digestion of $\mathrm{N}$ in the total digestive tract in the present study can be estimated to be 23.1 and $21.3 \mathrm{~g} \mathrm{~N} / \mathrm{d}$ for RP and EP diets, respectively. Summation of portal $\mathrm{N}$ net fluxes (ammonia, urea, FAA and PAA) was 26.7 and $25.0 \mathrm{~g} \mathrm{~N} / \mathrm{d}$, for RP and EP diets, respectively. The difference between $\mathrm{N}$ disappearance from the digestive tract and appearance into the portal blood was probably explained by urea and AA-N secretions into the digestive tract via saliva and bile, which are not taken into account in PDV measurements. The increase in RUP content of the diet through pea extrusion did not affect the summation of portal $\mathrm{N}$ net flux; however, it led to a $23 \%$ decrease in ammonia$\mathrm{N}$ absorption, a $21 \%$ increase in FAA-N absorption and a $15 \%$ decrease in net urea uptake by the gastrointestinal tract. Furthermore it decreased the fraction of total $\mathrm{N}$ (i.e. ammonia + FAA + PAA) absorbed as ammonia-N (from 63 to $53 \%$ ). From the literature, the effect of RUP content of the diet on AA net release in the portal vein is unclear. Using a combination of protein sources having different rumen degradability, a linear decrease in FAA net release across the PDV of steers was observed with RUP content of the diet ranging from 17 to $40 \%$ of total crude protein intake $^{(9)}$. Conversely, PDV net release of FAA increased 
(a)

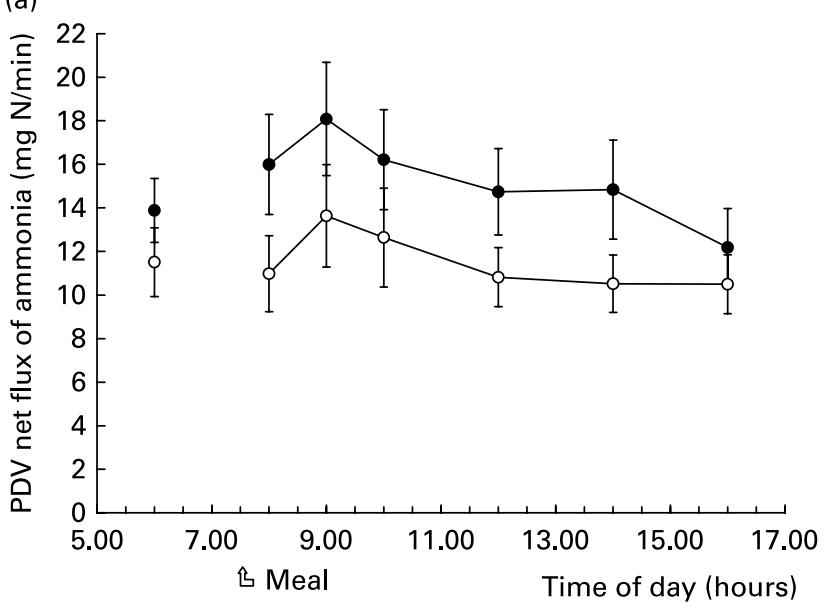

\begin{tabular}{lllllll} 
& & \multicolumn{3}{c}{ ₹ Meal } & \multicolumn{4}{c}{ Time of day (hours) } \\
(c) $\quad 5.00$ & 7.00 & 9.00 & 11.00 & 13.00 & 15.00 & 17.00
\end{tabular}
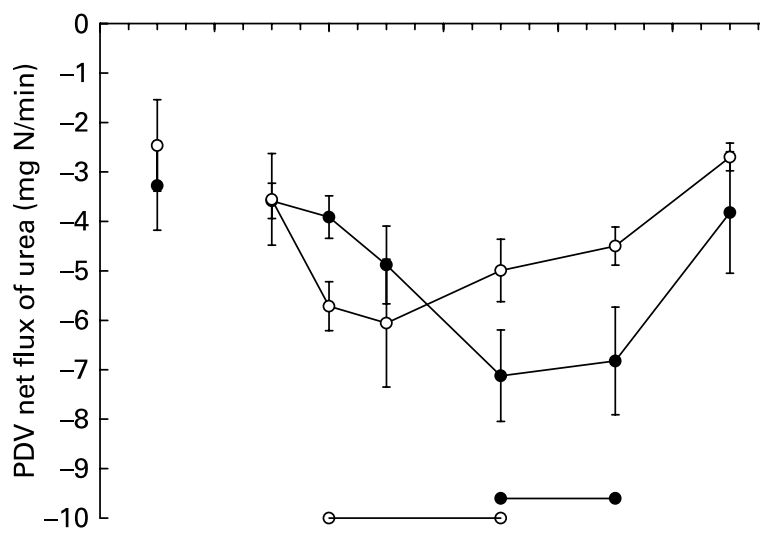

(b)

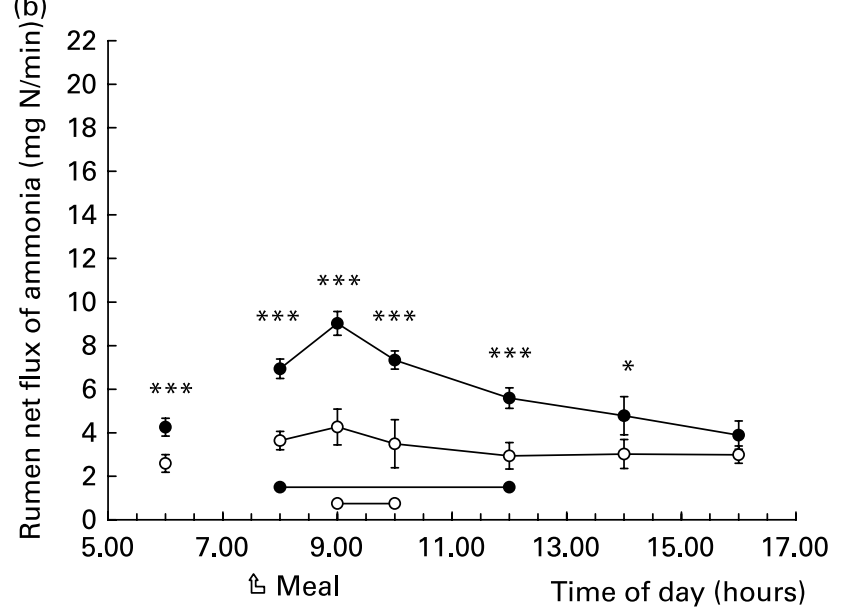

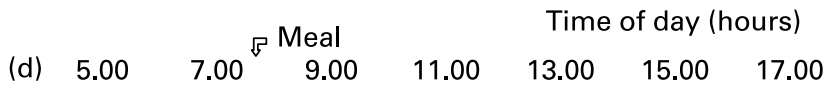

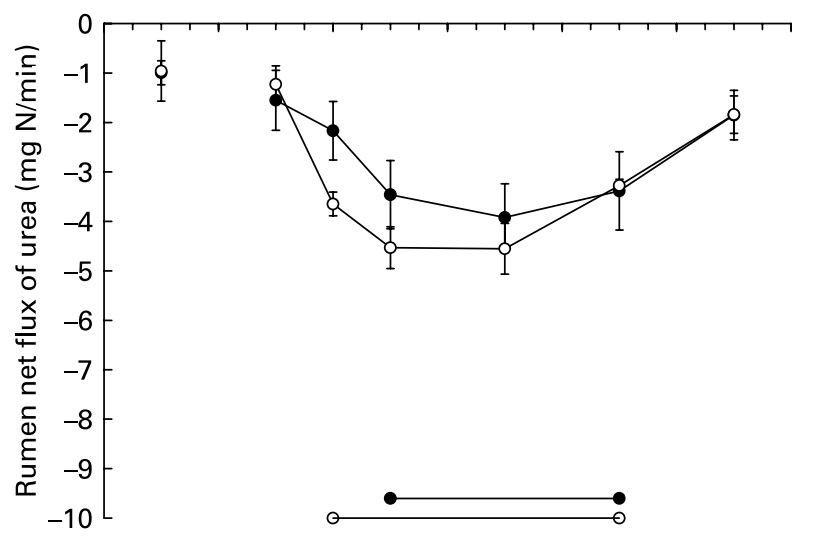

Fig. 2. Patterns of ammonia net flux across the portal-drained viscera (PDV; a) and the rumen (b), and urea net flux across the PDV (c) and the rumen (d) of sheep fed twice daily with cocksfoot hay supplemented with raw $(\bullet)$ or extruded $(O)$ pea seeds. Values are means with their standard errors depicted by vertical bars $(n 4)$. Data were analysed by a mixed-model ANOVA, and time $\times$ diet interaction was significant for ammonia net release across the rumen $(P<0.001)$ but not for the other measures. Mean values for the two diets were significantly different: ${ }^{\star} P<0.05$, ${ }^{\star \star \star} P<0.001$. Time effect was significant for the four measures $(P<0.001)$, and horizontal lines at the bottom of the graph indicate a significant difference $(P<0.05)$ from pre-meal value for each curve.

$(+26 \%)$ in lactating dairy cows, when RUP content of the diet increased from 25 to $37 \%$ of crude protein intake ${ }^{(8)}$. In agreement with this last study, the increase in RUP intake with pea extrusion in the present study (from 23 to $40 \%$ of crude protein intake) led to a $22 \%$ increase in PDV net release of FAA, demonstrating that when RUP content of the diet is increased, as long as duodenal flow of AA is increased, portal AA delivery is increased.

PAA net flux was not affected by the RUP content of the diet, conversely to what was observed in steers ${ }^{(9)}$, where PAA net release increased with RUP. Low-molecular-weight peptides accounted for 19 and $15 \%$ of non-protein AA (FAA + PAA) net release for RP and EP, respectively. This contribution with EP diet was lower than that previously observed using a similar diet with EP $(35 \%)^{(15)}$. This discrepancy between the two studies could be partly explained by the difference in feeding frequency (two times in the present study $v$. twelve times per day $\left.{ }^{(15)}\right)$, as peptide outflow from the rumen was shown to increase with feeding frequency ${ }^{(17)}$. However, the lack of increase in PDV net release of PAA is not consistent with the increased rumen peptide outflow with RP diet compared to EP diet. When considering all previous studies in which PAA were determined after $3 \mathrm{kDa}$ cut-off ultrafiltration, the contribution of low-molecular-weight peptides to non-protein AA net release across the PDV is rather homogenous, ranging from 15 to $35 \%^{(9,13,15,18)}$. Portal net release of PAA was increased when high concentrations of peptides were generated in the rumen ${ }^{(15)}$. Furthermore, it can be significantly affected by the diet composition ${ }^{(9,18)}$. These observations argue in favour of a possible absorption of luminal peptides from the gastrointestinal tract. Nevertheless, the contribution of luminal peptide absorption to PDV net release of PAA, in comparison with endogenous peptide net release, remains to be established.

\section{Nitrogen transactions across the rumen}

The present study showed that the improved duodenal balance observed with EP diet compared to RP diet in a previous study ${ }^{(10)}$ was mainly due to a reduction in rumen 


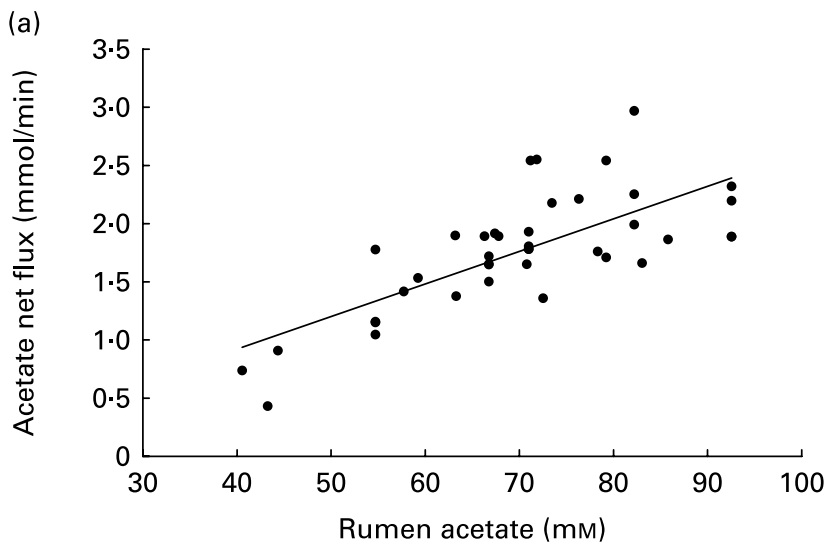

(b)

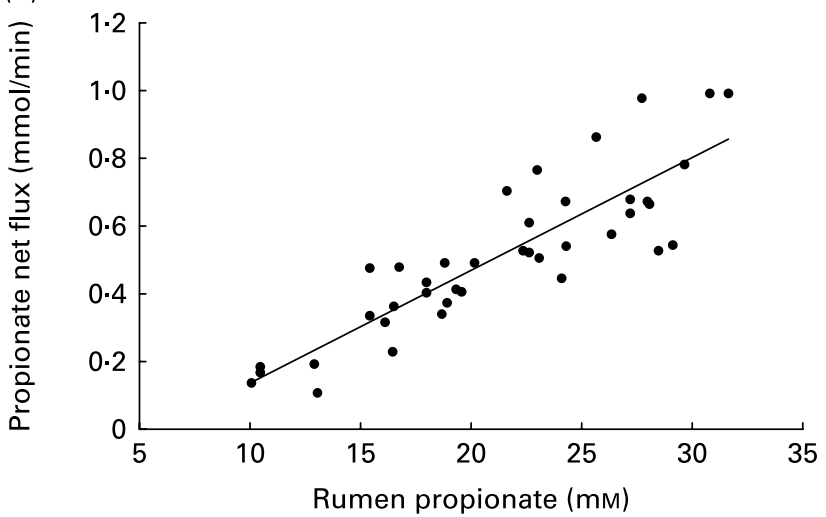

(c)

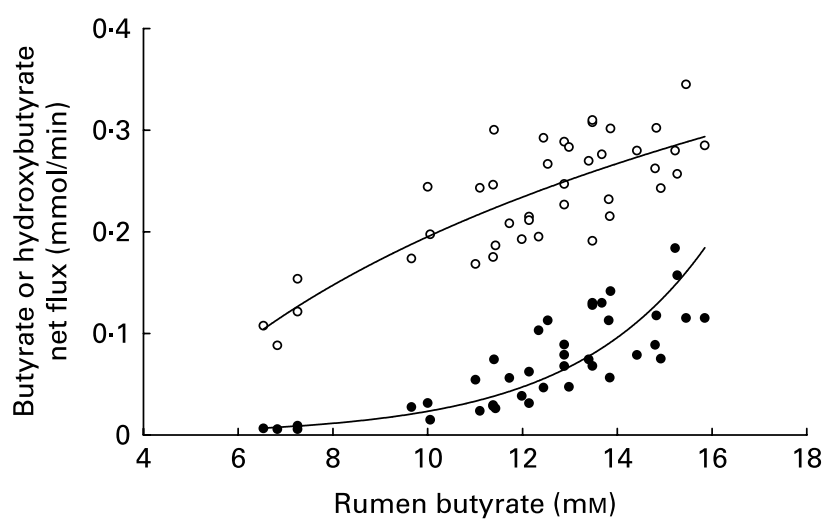

Fig. 3. Relationship between SCFA concentrations in the rumen and their instantaneous net fluxes across the rumen wall of sheep fed twice daily with cocksfoot hay supplemented with pea seeds. (a), Acetate, $y=0.0279 x-0.1953$, $R^{2}$ 0.5308; (b) proprionate, $y=0.0333 x-0.1962, R^{2} 0.7568$; (c) butyrate $(\bullet)$, $y=0.2139 \operatorname{Ln}(x)-0.2972, R^{2} 0.6374 ;$ hydroxybutyrate $(O), y=0.0007 \mathrm{e}^{0.3535 x}$ $R^{2} 0.8343$

ammonia-N net losses. Indeed, urea- $\mathrm{N}$ net transfer across the rumen wall was not affected by the diet, and urea entry into the rumen via saliva was probably reduced with EP owing to the decrease in blood urea concentration. The decrease in ammonia net release with pea extrusion was consistent with the decrease in average rumen ammonia concentration. The main factors acting on urea transfer across the ruminal epithelium have been reviewed by Rémond et al. ${ }^{(19)}$. Dietary regulation of this transfer involves changes in exchange 


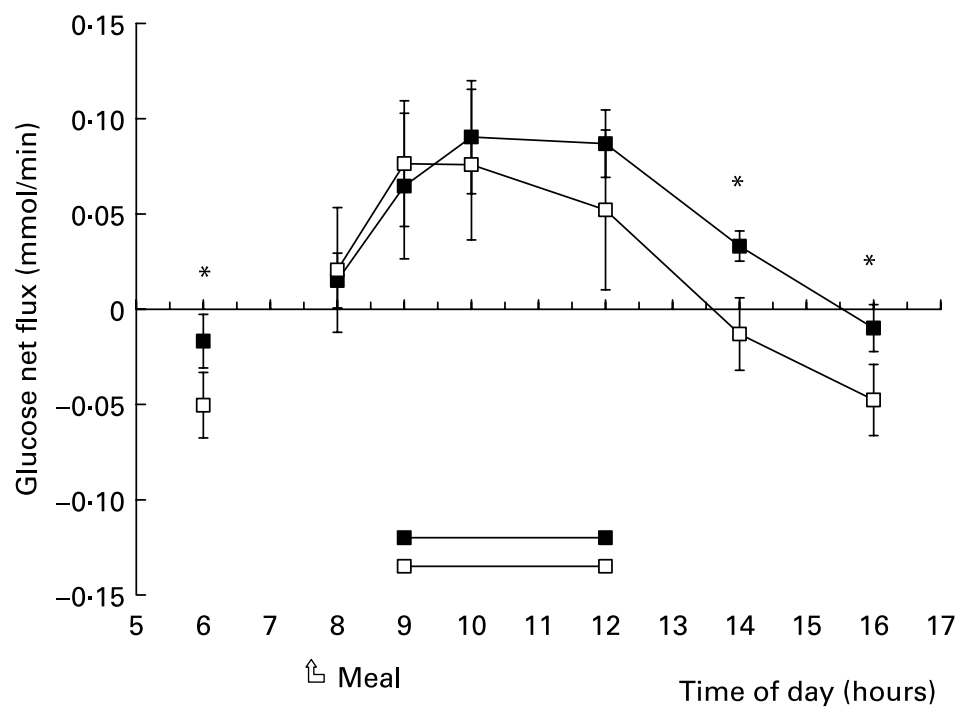

Fig. 4. Patterns of glucose net flux across the mesenteric-drained viscera ( $\square$ ) and portal-drained viscera ( $\square$ ) of sheep fed twice daily with cocksfoot hay supplemented with pea seeds. Values are means with their standard errors depicted by vertical bars ( $n$ 4). Data were analysed by a mixed-model ANOVA, and time effect was significant for the two measures $(P<0.001)$. Horizontal lines at the bottom of the graph indicate a significant difference $(P<0.05)$ from pre-meal value for each curve. Mean values were significantly different from those of the portal-drained viscera group (pairwise $t$ tests): ${ }^{\star} P<0 \cdot 05$.

surface between blood and rumen, governed by SCFA production, or changes in the urea concentration gradient (blood $v$. lumen) itself related to uraemia and luminal urease activity. In the present study, despite the decreased arterial urea concentration, urea net flux across the ruminal wall was maintained, and the extraction rate of arterial urea by the rumen wall (urea net flux expressed as a percentage of arterial urea influx) was nearly doubled with EP. As rumen SCFA concentration and absorption were not significantly affected, the most plausible explanation for this increased extraction rate with EP diet was an increased number and activity of ureolytic bacteria adhering to rumen epithelium, related to the decrease in ammonia concentration in rumen ${ }^{(20)}$. The contribution of the rumen to the PDV net flux of urea increased from 52 to $72 \%$ between RP and EP diet, evidencing the redistribution of urea net fluxes across the digestive compartments.
Rumen net uptake of FAA was not affected by pea extrusion, and was consistent with that reported for sheep fed fresh forage $^{(13)}$. However, its contribution to non-MDV net uptake of FAA was only $14 \%$ compare to the $33 \%$ observed with fresh forage.

\section{Nitrogen transactions across the mesenteric-drained viscera}

A cranial mesenteric vein blood flow probe and catheter were implanted before the junction with the ileocaecocolic vein. Therefore, MDV measurements in the present work represent net absorption across the small intestine. Hence, MDV blood flow accounted for $23 \%$ of the PDV blood flow, which is consistent with previous studies ${ }^{(13,15,16)}$. From data obtained with sheep from the same breed and similar diets ${ }^{(10)}$, total $\mathrm{N}$ flow at the duodenum in the present study (using DM intake as

Table 7. Portal-drained viscera (PDV), rumen and mesenteric-drained viscera (MDV) net flux of glucose, lactate, 3-hydroxybutyrate and volatile fatty acids in sheep fed cocksfoot hay supplemented with raw pea (RP) or extruded pea (EP) seeds*

(Mean values with their standard errors for four sheep)

\begin{tabular}{|c|c|c|c|c|c|c|c|c|c|c|c|c|c|c|c|}
\hline \multirow[b]{3}{*}{ Item } & \multicolumn{5}{|c|}{ PDV net flux (mmol/d) } & \multicolumn{5}{|c|}{ Rumen net flux (mmol/d) } & \multicolumn{5}{|c|}{ MDV net flux (mmol/d) } \\
\hline & \multicolumn{2}{|c|}{$\mathrm{RP}$} & \multicolumn{2}{|c|}{ EP } & \multirow[b]{2}{*}{$P$} & \multicolumn{2}{|c|}{$\mathrm{RP}$} & \multicolumn{2}{|c|}{ EP } & \multirow[b]{2}{*}{$P$} & \multicolumn{2}{|c|}{$\mathrm{RP}$} & \multicolumn{2}{|c|}{ EP } & \multirow[b]{2}{*}{$P$} \\
\hline & Mean & SE & Mean & SE & & Mean & SE & Mean & SE & & Mean & SE & Mean & SE & \\
\hline Glucose & $11 \cdot 8$ & 25 & $11 \cdot 5$ & 20 & 0.99 & -21 & 4 & -13 & 5 & 0.24 & $62 \cdot 2$ & 14 & 38.5 & 6 & 0.06 \\
\hline Lactate & 168 & 21 & 183 & 35 & 0.81 & 109 & 8 & 146 & 19 & 0.23 & 3 & 9 & 5 & 4 & 0.92 \\
\hline $\begin{array}{l}\text { 3-Hydroxybutyrate } \\
\text { Volatile fatty acids }\end{array}$ & 515 & 32 & 445 & 29 & 0.11 & 359 & 18 & 305 & 30 & 0.03 & -26 & 3 & -26 & 3 & 0.89 \\
\hline Acetate & 4139 & 77 & 4318 & 411 & 0.72 & 2419 & 108 & 2336 & 156 & 0.73 & -427 & 77 & -316 & 115 & 0.17 \\
\hline Propionate & 1305 & 102 & 1525 & 124 & 0.06 & 634 & 78 & 699 & 76 & 0.65 & 7 & 8 & 29 & 19 & 0.18 \\
\hline Butyrate & 193 & 28 & 164 & 20 & 0.18 & 102 & 13 & 74 & 11 & 0.24 & -6 & 2 & -2 & 2 & 0.15 \\
\hline Isobutyrate & 59 & 2 & 52 & 3 & 0.14 & 27 & 1 & 19 & 2 & 0.07 & 1 & 0 & 2 & 1 & 0.11 \\
\hline Valerate & 18 & 2 & 18 & 2 & 0.56 & 7 & 1 & 6 & 1 & 0.67 & 0 & 0 & 1 & 1 & 0.07 \\
\hline Isovalerate & 49 & 3 & 37 & 2 & 0.08 & 23 & 2 & 14 & 2 & 0.00 & 0 & 1 & 2 & 1 & 0.04 \\
\hline
\end{tabular}

${ }^{*}$ For details of procedures and diets, see the Materials and methods section and Table 1. 
correcting factor) can be estimated to be 31.5 and $38.8 \mathrm{~g} \mathrm{~N} / \mathrm{d}$ with RP and EP diets, respectively. Similarly, N apparent disappearance from the small intestine can be estimated to be 19.5 and $23 \mathrm{~g} \mathrm{~N} / \mathrm{d}$. Summation of FAA, PAA, ammonia and urea net fluxes across the MDV was 21.9 and $24.1 \mathrm{~g}$ $\mathrm{N} / \mathrm{d}$. The slight discrepancy between $\mathrm{N}$ apparent disappearance from the small intestine and apparent $\mathrm{N}$ appearance across the MDV has been already observed and discussed ${ }^{(13)}$. A $32 \%$ increase in total AA apparent disappearance from the small intestine was reported between RP and EP diets ${ }^{(10)}$. The increase in total AA (FAA + PAA) net release across the MDV in the present study was only $12 \%$, suggesting either an increased AA catabolism within the MDV, or an increased exported protein (or large peptide) synthesis by the MDV with EP diet. Individual duodenal flow of essential AA in the present study can be estimated from our previous study ${ }^{(10)}$. With respect to estimated duodenal flow, pea extrusion slightly decreased the apparent MDV recovery of all essential AA flowing into the duodenum (Fig. 5). As small intestinal digestibility of the rumen undegraded $\mathrm{N}$ of pea is not decreased by extrusion ${ }^{(10)}$, this would suggest that the essential AA utilization by the small intestine increases with duodenal flow. Whatever the diet, PAA net release across the MDV was not significantly different from PDV net release; and, as observed in sheep fed fresh forage ${ }^{(13)}$, the small intestine was the main contributor to PAA net release across the PDV (56\%). Peptide contribution to MDV net release of essential AA was only $7-8 \%$, with this contribution being slightly lower than previously reported in sheep $(14 \%)^{(13)}$, and in lambs (up to $\left.20 \%\right)^{(21)}$. Urea transfer to the small intestine, and its contribution to urea net uptake across the PDV, decreased with pea extrusion, probably as a consequence of the decrease in blood urea concentration.

\section{Nitrogen transactions across the non-mesenteric-drained} viscera

The PDV:MDV appearance ratio of essential FAA reported in the literature ranged from $0 \cdot 60$ to $0 \cdot 80^{(9,13,22,23)}$, evidencing the large use of arterial essential FAA by non-MDV tissues. The ratio observed in the present study (65 and $69 \%$ for RP and EP diets, respectively) is consistent with the literature. While it was not affected by the dietary treatment for valine, isoleucine, lysine, histidine and methionine, it increased with pea extrusion for theonine, leucine and phenylalanine. Conversely to what was reported for steers $^{(24,25)}$, and apart from particular situations generating high concentration of specific peptides in the rumen ${ }^{(26)}$, the present study supports previous observations according to which absorption of PAA from the forestomach of sheep is low, and not affected by RUP content of the diet.

\section{Net fluxes of energy substrates}

Net portal appearance of energy as SCFA, 3-hydroxybutyrate, lactate, glucose, FAA and PAA averaged $83 \%$ of metabolizable energy intake. Missing energy could be mainly explained by PDV energy expenditure. Indeed, according to a recent meta-analysis, oxygen consumption at this level of intake may account for nearly $20 \%$ of metabolizable energy intake ${ }^{(27)}$. The energy reaching the portal vein was distributed among SCFA ( $66 \%$ of net portal appearance of energy), AA (20\%), 3-hydroxybutyrate (11\%), lactate (2\%) and glucose (less than $1 \%$ ). This is consistent with several other studies $^{(28,29)}$. Net fluxes of energy substrates were either affected or unaffected by the diet. Nevertheless the present study provides some interesting information regarding the partitioning of energy substrate net fluxes among the PDV.

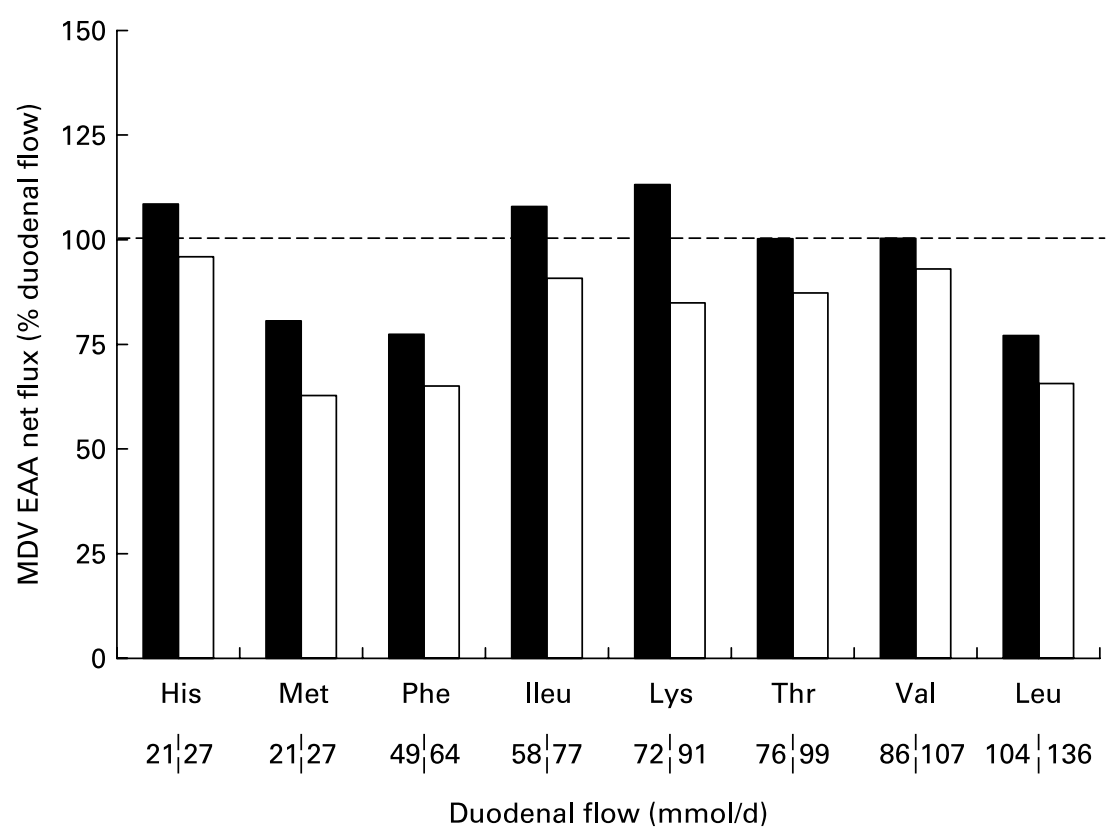

Fig. 5. Essential amino acid (free + peptide; EAA) net flux across the mesenteric-drained viscera (MDV) of sheep fed twice daily with cocksfoot hay supplemented with raw $(\square)$ or extruded $(\square)$ pea seeds; fluxes are expressed as a proportion of duodenal flow estimated from Poncet \& Rémond ${ }^{(10)}$. His, histidine; Ileu, isoleucine; Leu, leucine; Lys, lysine; Met, methionine, Phe, phenylalanine; Thr, threonine; Val, valine. 
The rumen contribution to PDV net flux of SCFA and 3-hydroxybutyrate averaged 54 and $69 \%$, respectively, which was slightly lower than that reported for sheep fed fresh forage (65 and $77 \%$, respectively) ${ }^{(13)}$, suggesting a greater contribution of the hindgut to total SCFA production. Nevertheless, it confirms that rumen accounts for less than two-thirds of the PDV net release of SCFA, the remaining being derived from ruminally produced SCFA that are absorbed across the reticulum-omasum-abomasum and SCFA produced and absorbed across the large intestine. Non-rumen and non-MDV tissues include organs where SCFA absorption takes place (omasum, abomasum, hindgut), but also tissues that are potential users of arterial acetate and 3-hydroxybutyrate. As previously observed ${ }^{(13)}$, small intestine exhibits a large net uptake of acetate and 3-hydroxybutyrate, reflecting extraction rates averaging, respectively, 31 and $4 \%$ of arterial supply in the present work. As a result, the contribution of the rumen to the PDV net release is greater for acetate $(56 \%)$ and 3-hydroxybutyrate $(69 \%)$ than for other SCFA (on average $47 \%$ ).

Since the ruminal concentrations of SCFA is not necessarily related to their ruminal production or absorption rates, especially with high concentrate diets inducing low ruminal $\mathrm{pH}$, the comparison between ruminal concentrations and portal or ruminal net appearance is often hazardous. Nevertheless, in the present work, for which a moderate postprandial drop in $\mathrm{pH}$ was observed, a close and linear relationship between ruminal concentrations and rumen net appearance was observed for acetate and propionate. The slope was similar for both acetate and propionate, suggesting a similar firstpass extraction rate by the rumen wall. Also, the linearity revealed that constant proportions of the acetate and propionate are extracted by the rumen wall during the absorption process. In contrast, the relationships between ruminal concentrations and rumen net appearance appeared non-linear for butyrate, furthermore the relationship between rumen net appearance of butyrate and 3-hydroxybutyrate reveals a plateau for 3-hydroxybutyrate, suggesting a limitation of ketogenesis during the peak of butyrate absorption.

Pea extrusion is known to slightly increase in sacco degradability of $\operatorname{starch}^{(30)}$. However, the in vivo rumen starch digestibility measured with similar diets did not differ between RP and EP $(87 \%)^{(10)}$ and it can be estimated that about $23 \mathrm{~g}$ starch/d reached the duodenum with both RP and EP diets in the present study. Apparent recoveries of starch glucose across the MDV and PDV, as determined by the area under the curve method, were not different between diets and accounted for 70-80\% of starch entering the small intestine. These values are minimal ones, indeed starch digestibility in the small intestine for ground grains is generally lower than $90 \%^{(31,32)}$. Furthermore, arterial glucose uptake by the PDV increases when intestinal glucose is provided $^{(33,34)}$, which tends to underestimate the true release of dietary glucose. Such high recovery of starch glucose is in agreement with the observations in dairy cows receiving a pulse dose of glucose infused into the abomasum $^{(35)}$, suggesting a low first-pass utilization of dietary glucose by the small intestine. Nevertheless pre-feeding values of portal glucose net flux showed a significant uptake of arterial glucose by the PDV, the MDV accounting for about one-third of this uptake.

\section{Conclusion}

The partial shift in pea protein digestion from the rumen to the small intestine using extrusion did not affect the portal net balance of $\mathrm{N}$, but it decreased $\mathrm{N}$ loss from the rumen, and increased AA intestinal absorption and portal delivery. Although the daily net flux of urea across the rumen wall has not been significantly increased, the extraction rate of arterial urea by the rumen wall was nearly doubled with EP, evidencing a better efficiency in urea-N recycling. Peptide concentration in the rumen was largely increased with EP; however, this did not impact on portal net release of peptide.

\section{Acknowledgements}

The authors wish to thank J. Lefaivre for surgery, J. P. Chaise for animal care, S. Gachon, B. Duriot and E. Delval for laboratory analyses, and F. Glasser for data analysis, and help in interpretation. With special thanks to C. Poncet who contributed to discussions and elaboration of the experiment. The author's contribution were as follows: D. R. planned and implemented the study, analysed statistics, interpreted the data, and prepared the manuscript; I. S.-A. interpreted the data and was involved in the critical revision of the manuscript; L. B. designed and implemented the study, and was involved in the critical revision of the manuscript; P. N. interpreted the data and prepared the manuscript. The study was supported by the Institut National de la Recherche Agronomique. None of the authors had a conflict of interest.

\section{References}

1. Poncet C, Michalet-Doreau B, McAllister T, et al. (1995) Dietary compounds escaping rumen digestion. In Recent Developments in the Nutrition of Herbivores. Proceedings of the IVth International Symposium on the Nutrition of Herbivores Clermont-Fd - France, pp. 167-204 [M Journet, E Grenet, MH Farce, M Theriez and C Demarquilly, editors]. Versaille, France: INRA editions.

2. Lobley GE (2003) Protein turnover - what does it mean for animal production? Can J Anim Sci 83, 327-340.

3. MacRae JC, Bruce LA, Brown DS, et al. (1997) Amino acid use by the gastrointestinal tract of sheep given lucerne forage. Am J Physiol Gastrointest Liver Physiol 273, G1200-G1207.

4. Reynolds CK (2006) Splanchnic amino acid metabolism in ruminants. In Ruminant Physiology: Digestion, Metabolism and Impact of Nutrition on Gene Expression, Immunology and Stress, pp. 225-248 [K Sejrsen, T Hvelplund and MO Nielsen, editors]. Wageningen, The Netherlands: Wageningen Academic Publishers.

5. Huntington GB (1987) Net absorption from portal-drained viscera of nitrogenous compounds by beef heifers fed on diets differing in protein solubility or degradability in the rumen. $\mathrm{Br} J$ Nutr 57, 109-114.

6. Ferrell CL, Kreikemeier KK \& Freetly HC (1999) The effect of supplemental energy, nitrogen, and protein on feed intake, digestibility, and nitrogen flux across the gut and liver in sheep fed low-quality forage. J Anim Sci 77, 3353-3364.

7. Bohnert DW, Larson BT, Lewis SJ, et al. (1999) Net nutrient flux in visceral tissues of lambs fed diets differing in supplemental nitrogen source. J Anim Sci 77, 2545-2553.

8. Blouin JP, Bernier JF, Reynolds CK, et al. (2002) Effect of supply of metabolizable protein on splanchnic fluxes of 
nutrients and hormones in lactating dairy cows. J Dairy Sci $\mathbf{8 5}$, $2618-2630$

9. Han XT, Xue B, Hu LH, et al. (2001) Effect of dietary protein degradability on net fluxes of free and peptide amino acids across the portal-drained viscera of steers. J Agric Sci Camb 137, 471-481.

10. Poncet C \& Rémond D (2002) Rumen digestion and intestinal nutrient flows in sheep consuming pea seeds: the effect of extrusion or chestnut tannin addition. Anim Res 51, 201-216.

11. Rémond D, Le Guen MP \& Poncet C (2003) Degradation in the rumen and nutritional value of lupin (Lupinus albus L.) seed proteins: effect of extrusion. Anim Feed Sci Technol 105, $55-70$.

12. Raggio G, Pacheco D, Berthiaume R, et al. (2004) Effect of level of metabolizable protein on splanchnic flux of amino acids in lactating dairy cows. J Dairy Sci 87, 3461-3472.

13. Rémond D, Bernard L, Chauveau B, et al. (2003) Digestion and nutrient net fluxes across the rumen, and the mesenteric- and portal-drained viscera in sheep fed with fresh forage twice daily: net balance and dynamic aspects. Br J Nutr 89, 649-666.

14. Reynal SM, Ipharraguerre IR, Lineiro M, et al. (2007) Omasal flow of soluble proteins, peptides, and free amino acids in dairy cows fed diets supplemented with proteins of varying ruminal degradabilities. J Dairy Sci 90, 1887-1903.

15. Rémond D, Bernard L \& Poncet C (2000) Free and peptide amino acid net flux across the rumen and the mesenteric- and portal-drained viscera of sheep. J Anim Sci 78, 1960-1972.

16. Neutze SA, Oddy VH \& Gooden JM (1994) A cranial mesenteric vein preparation for measurement of amino acid uptake by lambs. J Agric Sci 122, 309-314.

17. Chen G, Sniffen CJ \& Russel JB (1987) Concentration and estimated flow of peptides from the rumen of dairy cattle: effects of protein quantity, protein solubility, and feeding frequency. J Dairy Sci 70, 983-992.

18. Tagari H, Webb K Jr, Theurer B, et al. (2004) Portal drained visceral flux, hepatic metabolism, and mammary uptake of free and peptide-bound amino acids and milk amino acid output in dairy cows fed diets containing corn grain steam flaked at 360 or steam rolled at $490 \mathrm{~g} / \mathrm{L}$. J Dairy Sci 87, 413-430.

19. Rémond D, Meschy F \& Boivin R (1996) Metabolites, water and mineral exchange across the rumen wall: mechanisms and regulation. Ann Zootech 45, 97-119.

20. Cheng KJ \& Wallace RJ (1979) The mechanism of passage of endogenous urea through the rumen wall and the role of ureolytic epithelial bacteria in the urea flow. Br J Nutr 42, 553-557.

21. Neutze SA, Gooden JM \& Oddy VH (1996) Uptake of labelled phenylalanine in to different blood fractions in the portal vein and cranial mesenteric vein in lambs. J Agric Sci Camb 126, 511-518.

22. MacRae JC, Bruce LA, Brown DS, et al. (1997) Absorption of amino acids from the intestine and their net flux across the mesenteric- and portal-drained viscera in lambs. J Anim Sci 75, 3307-3314.

23. Lobley GE, Shen X, Le G, et al. (2003) Oxidation of essential amino acids by the ovine gastrointestinal tract. Br J Nutr 89, 617-629.

24. Koeln LL, Schlagheck TG \& Webb KE (1993) Amino acid flux across the gastrointestinal tract and liver of calves. J Dairy $S c i$ 76, 2275-2285.

25. Seal CJ \& Parker DS (1996) Effect of intraruminal propionic acid infusion on metabolism of mesenteric- and portal-drained viscera in growing steers fed a forage diet: II. Ammonia, urea, amino acids and peptides. J Anim Sci 74, 245-256.

26. Rémond D, Bernard L \& Poncet C (2000) Amino acid flux in ruminal and gastric veins of sheep: effects of ruminal and omasal injections of free amino acids and carnosine. J Anim Sci 78, 158-166.

27. Bermingham EN, Nozière $P$, Vernet $J$, et al. (2008) The relationships between intake and net portal fluxes of energy metabolites in ruminants: a meta-analysis. Anim Feed Sci Technol 148, 27-58.

28. Lindsay DB (1993) Metabolism of the portal drained viscera. In Quantitative Aspects of Ruminant Digestion and Metabolism, pp. 267-289 [JM Forbes and J France, editors]. Wallingford, UK: CAB International.

29. Ortigues I \& Visseiche AL (1995) Whole body fuel selection in ruminants: nutrient supply and utilization by major tissues. Proc Nutr Soc 54, 235-251.

30. INRA (2007) Alimentation des Bovins, Ovins et Caprins, Besoins des Animaux - Valeurs des Aliments (Food of Cows, Sheep and Goats, Needs of Animals-Food Values). Versaille, France: Quae.

31. Rémond D, Cabrera-Estrada JI, Champion M, et al. (2004) Effect of corn particle size on site and extent of starch digestion in lactating dairy cows. J Dairy Sci 87, 1389-1399.

32. Ramos BMO, Champion M, Poncet C, et al. (2009) Effects of vitreousness and particle size of maize grain on ruminal and intestinal in sacco degradation of dry matter, starch and nitrogen. Anim Feed Sci Technol 148, 253-266.

33. Piccioli Cappelli F, Seal CJ \& Parker DS (1997) Glucose and $\left[{ }^{13} \mathrm{C}\right]$ leucine metabolism by the portal-drained viscera of sheep fed on dried grass with acute intravenous and intraduodenal infusions of glucose. Br J Nutr 78, 931-946.

34. Nozière $\mathrm{P}$, Rémond $\mathrm{D}$, Lemosquet $\mathrm{S}$, et al. (2005) Effect of site of starch digestion on portal nutrient net fluxes in steers. $\mathrm{Br} \mathrm{J}$ Nutr 94, 182-191.

35. Larsen M \& Kristensen NB (2007) Portal recovery of glucose infused into the abomasums of lactating dairy cows. In Energy and Protein Metabolism and Nutrition. EAAP Publication no. 124, pp. 339-340 [I Ortigues-Marty, N Miraux and W Brand-Williams, editors]. Wageningen, The Netherlands: Wageningen Academic Publishers. 